\title{
Deoxyribonucleic Acid Base Composition of Prosthecomicrobium and Ancalomicrobium Strains
}

\author{
J. T. STALEY and M. MANDEL \\ Department of Microbiology, University of Washington, Seattle, Washington 98195, and the \\ Department of Biology, The University of Texas, M.D. Anderson Hospital and Tumor \\ Institute at Houston, Houston, Texas 77025
}

\begin{abstract}
The deoxyribonucleic acid base compositions of 14 newly isolated strains and the type strains of Prosthecomicrobium enhydrum, $P$. pneumaticum, and Ancalomicrobium adetum are reported. The guanine plus cytosine values of these strains range from 66.1 to $71.4 \mathrm{~mol} \%$.
\end{abstract}

The genera Prosthecomicrobium and $A n$ calomicrobium are currently represented by only four isolates, three of which are the type strains of Prosthecomicrobium enhydrum, $P$. pneumaticum, and $A$. adetum (6). Our understanding of the biological diversity of these genera has been limited by the availability of additional strains. In this paper we report the isolation of 14 new strains and their deoxyribonucleic acid (DNA)-base composition values or GC values (ratio of moles percent guanine plus cytosine to total bases) as determined by buoyant-density centrifugation in $\mathrm{CsCl}$.

Most of the isolates were obtained from dilute peptone enrichment cultures prepared by adding $100 \mathrm{ml}$ of a freshwater sample to a sterile, $150-\mathrm{ml}$ beaker containing $10 \mathrm{mg}$ of peptone (Difco) and covered with aluminum foil. These were incubated at 20 to $25 \mathrm{C}$ for 3 to 5 weeks to allow these prosthecate bacteria to reach their maximum cell densities. Portions were then streaked or spread on peptone agar containing $0.01 \%$ peptone, $20 \mathrm{ml}$ of Hutner's modified mineral salts solution (7) per $\mathrm{ml}, 10$ $\mathrm{ml}$ of a vitamin solution (6) per liter, and $1.5 \%$ agar, at $\mathrm{pH}$ 7.0. After incubation for 10 to 20 days, wet mounts of individual colonies were examined with the phase microscope to locate multiple appendaged bacteria resembling those in the genera Prosthecomicrobium and $A n$ calomicrobium. These were then purified by restreaking on MMB agar containing $0.015 \%$ peptone, $0.015 \%$ yeast extract (Difco), $0.025 \%$ ammonium sulfate, and $0.1 \%$ glucose with the mineral salts and vitamin solutions.

By using the above procedures, the 14 new isolates listed in Table 1 were obtained from creeks, rivers, ponds, and lakes at several locales in the United States. The DNA was extracted according to the procedure of Marmur (2); some strains required extended incubation with lysozyme ( 1.5 to $2 \mathrm{~h}$ ) to effect lysis. Buoyant densities (in neutral $\mathrm{CsCl}$ ) and $\mathrm{GC}$ contents of the DNA samples were determined by using DNA of bacteriophage $2 \mathrm{C}(\rho=1.742 \mathrm{~g}$ per $\mathrm{cm}^{3}$ ) as the internal reference (5). The new strains are listed together with the type strains in increasing order of GC values in Table 1 .

These data are noteworthy for the following reasons: (i) this is the first report of the GC value for $A$. adetum and its type strain; (ii) at intermediate $\mathrm{GC}$ values the strains have either short prosthecae (conical in shape and less than $2 \mu \mathrm{m}$ in length) or short and long prosthecae (cylindrical in shape and greater than $2 \mu \mathrm{m}$ in length), whereas at the low extreme values the appendages are short and at the high extreme values the appendages are long; (iii) those strains that have gas vacuoles have high GC values; (iv) the spread in GC values in these genera is comparable in magnitude to that of other prosthecate bacterial groups, namely, Caulobacter (4) and Hyphomicrobium (1, 3).

A fuller description of these strains, including studies of their morphology, nutrition, metabolism, life cycles, and DNA homologies, is being undertaken to better assess the biological diversity within this group.

This investigation was supported in part by National Science Foundation grant GB-30313. We wish to acknowledge the technical assistance of J. Dalmasso and E. Edlin. We thank M. Van Ert, P. Stanley, and J. Babinchak for providing some of the new isolates. 
TABLE 1. Some properties of isolates of Prosthecomicrobium and Ancalomicrobium

\begin{tabular}{|c|c|c|c|c|c|c|}
\hline \multirow[b]{2}{*}{$\begin{array}{l}\text { Strain no. } \\
\text { or name }\end{array}$} & \multirow[b]{2}{*}{ Source } & \multicolumn{3}{|c|}{ Morphology } & \multicolumn{2}{|c|}{$\begin{array}{l}\text { Deoxyribonucleic } \\
\operatorname{acid}^{b}\end{array}$} \\
\hline & & Prosthecae $^{a}$ & Motility & $\begin{array}{c}\text { Gas } \\
\text { vacuoles }\end{array}$ & $\begin{array}{c}\mathrm{CsCl} \\
\text { density } \\
\left(\mathrm{g} / \mathrm{cm}^{3}\right)\end{array}$ & $\begin{array}{c}\text { Guanine + } \\
\text { cytosine } \\
(\mathrm{mol} \%)\end{array}$ \\
\hline $\begin{array}{l}\text { Prosthecomicrobium } \\
\text { enhvdrum } \\
\text { (ATCC 23634) }, d\end{array}$ & $\begin{array}{l}\text { Putah Creek Overflow, } \\
\text { Davis, Calif. }\end{array}$ & Short & + & - & $\begin{array}{l}1.7248 \\
(4)\end{array}$ & 66.1 \\
\hline 1 & $\begin{array}{l}\text { Lake Lansing, Lansing, } \\
\text { Mich. }\end{array}$ & Short & - & - & 1.7255 & 66.8 \\
\hline 2 & $\begin{array}{l}\text { Lake Lansing, Lansing, } \\
\text { Mich. }\end{array}$ & Short & - & - & $\begin{array}{l}1.7257 \\
\text { (3) }\end{array}$ & 67.0 \\
\hline 6 & $\begin{array}{l}\text { Red Cedar River, } \\
\text { Lansing, Mich. }\end{array}$ & Short and long & + & - & 1.7265 & 67.9 \\
\hline 5 & $\begin{array}{l}\text { Lawrence Lake, Hickory } \\
\text { Corners, Mich. }\end{array}$ & Short & + & - & 1.727 & 68.4 \\
\hline 14 & $\begin{array}{l}\text { Muskrat Pond, Chapel Hill, } \\
\text { N. C. (by M. Van Ert) }\end{array}$ & Short and long & + & - & 1.727 & 68.4 \\
\hline 10 & $\begin{array}{l}\text { Wintergreen Lake, Hickory } \\
\text { Corners, Mich. }\end{array}$ & Short and long & + & - & 1.7275 & 68.9 \\
\hline 11 & $\begin{array}{l}\text { Kellogg Forest Pond, } \\
\text { Hickory Corners, Mich. }\end{array}$ & Short and long & + & - & 1.7275 & 68.9 \\
\hline 12 & $\begin{array}{l}\text { Bolin Creek, Chapel Hill, } \\
\text { N. C. }\end{array}$ & Short and long & + & - & 1.7275 & 68.9 \\
\hline 16 & $\begin{array}{l}\text { Muskrat Pond, Chapel Hill, } \\
\text { N. C. }\end{array}$ & Short and long & + & - & 1.7275 & 68.9 \\
\hline 15 & $\begin{array}{l}\text { Muskrat Pond, Chapel Hill, } \\
\text { N. C. } \\
\text { (by M. Van Ert) }\end{array}$ & Short and long & + & - & 1.7275 & 68.9 \\
\hline 17 & $\begin{array}{l}\text { Bitter Lake, Seattle, } \\
\text { Wash. }\end{array}$ & Short & - & - & 1.7275 & 68.9 \\
\hline $\begin{array}{l}\text { Prosthecomicrobium } \\
\text { pneumaticum } \\
(\text { ATCC 23633) }\end{array}$ & $\begin{array}{l}\text { Putah Creek Overflow, } \\
\text { Davis, Calif. }\end{array}$ & $\begin{array}{l}\text { Short } \\
\text { (rarely long) }\end{array}$ & - & + & 1.728 & 69.4 \\
\hline 7 & $\begin{array}{l}\text { Temporary Pond, } \\
\text { Ann Arbor, Mich. } \\
\text { (by J. Babinchak) }\end{array}$ & Short and long & + & - & 1.7285 & 69.9 \\
\hline 19 & $\begin{array}{c}\text { Pulp Mill Oxidation Pond, } \\
\text { Ore. (by Patricia Stanley) }\end{array}$ & Short & - & + & 1.729 & 70.4 \\
\hline $\begin{array}{l}\text { Ancalomicrobium } \\
\text { adetum } \\
\text { (ATCC 23632) }^{c}\end{array}$ & $\begin{array}{l}\text { Putah Creek Overflow, } \\
\text { Davis, Calif. }\end{array}$ & Long & - & + & 1.729 & 70.4 \\
\hline 18 & $\begin{array}{l}\text { Pulp Mill Oxidation Pond, } \\
\text { Ore. }\end{array}$ & Long & - & - & 1.730 & 71.4 \\
\hline
\end{tabular}

${ }^{a}$ Short prothecae are conical in shape and less than $2 \mu \mathrm{m}$ long; long prosthecae are cylindrical and greater than $2 \mu \mathrm{m}$ long.

${ }^{b}$ Average of at least duplicate analyses; parentheses give number of analyses if more than two.

$c$ Type strains.

${ }^{d}$ ATCC, American Type Culture Collection, Rockville, Md.

\section{REPRINT REQUESTS}

Address requests for reprints to: James T. Staley, School of Medicine, Department of Microbiology, University of Washington, Seattle, Washington 98105 .

\section{LITERATURE CITED}

1. Mandel, M., P. Hirsch, and S. F. Conti. 1972. Deoxyribonucleic acid base compositions of hyphomicrobia. Arch. Mikrobiol. 81:289-294.

2. Marmur, J. 1961. A procedure for the isolation of deoxyribonucleic acid from microorganisms. J. Mol. Biol. 3:208-218.

3. Moore, R. L., and P. Hirsch. 1972. Deoxyribonucleic acid base sequence homologies of some budding and prosthecate bacteria. J. Bacteriol. 110:256-261.

4. Poindexter, J. S. 1964. Biological properties and classification of the Caulobacter group. Bacteriol. Rev. 28:231-295. 
5. Schildkraut, C. L., J. Marmur, and P. Doty. 1962. Determination of the base composition of deoxyribonucleic acid from its buoyant density in $\mathrm{CsCl}$. J. Mol. Biol. 4:430-433.

6. Staley, J. T. 1968. Prosthecomicrobium and An- calomicrobium: new prosthecate freshwater bacteria. J. Bacteriol. 95:1921-1942.

7. Van Ert, M., and J. T. Staley. 1971. Gas vacuolated strains of Microcyclus aquaticus. J. Bacteriol. 108:236-240. 